\title{
Alternative sources of potassium for maize cultivation
}

\section{Fontes alternativas de potássio para o cultivo do milho}

\author{
Paulo Fernandes Boldrin $^{1 *}$ (D) , Hugo Ferreira Souto ${ }^{1}$ (D) , Lenise Selaysim Salles ${ }^{1}$ (D) , Antonio Eduardo Furtini Neto ${ }^{2}$ (D)
}

${ }^{1}$ Universidade de Rio Verde, Fazenda Fontes do Saber, Rio Verde, GO, Brasil

Universidade Federal de Lavras/UFLA, Departamento de Ciência do Solo, Lavras, MG, Brasil

${ }^{*}$ Corresponding author: pfboldrin@gmail.com

Received in October 4, 2019 and approved in December 19, 2019

\begin{abstract}
Brazil is the largest importer of potassium (K) fertilizers in the world, importing about $95 \%$ of all the potassium consumed by its agriculture. Thus, new sources and technologies to increase $\mathrm{K}$ availability have been studied. This study aimed to evaluate the agronomic viability of the use of calcined glauconite and phonolite blended and granulated with two organic materials on maize growth in pots, using two soils of contrasting texture in a controlled environment. Were evaluated eight sources of potassium: phonolite; phonolite + poultry manure; phonolite + cattle manure; calcined glauconite; calcined glauconite + poultry manure; calcined glauconite + cattle manure; negative control (no K); and positive control ( $\mathrm{K}-\mathrm{KCl}$ ), and two soils of contrasting texture. The experiment was carried out for $38 \mathrm{~d}$. The following parameters were analyzed: plant height, stem diameter, shoot dry mass, leaf number, leaf contents of nitrogen ( $N$ ), $K$ and phosphorus $(\mathrm{P})$, and the SPAD chlorophyll meter. In the sandy soil, the source consisting of phonolite + chicken manure was similar to $\mathrm{KCl}$ application regarding plant height, stem diameter and shoot dry mass. As for the clayey soil, when both rocks were blended with the organic wastes, they were similar to $\mathrm{KCl}$ for shoot dry mass. The use of pure granulated rocks, calcined glauconite and phonolite without blending with the organic residues is not efficient to provide available $\mathrm{K}$ to maize plants.
\end{abstract}

Index terms: Zea mays; phonolite; calcined glauconite.

\begin{abstract}
RESUMO
O Brasil importa aproximadamente $95 \%$ dos fertilizantes potássicos usados na agricultura, e, novas fontes e tecnologias para aumentar a disponibilidade do nutriente têm sido estudadas. Objetivou-se avaliar a viabilidade agronômica de uso da glauconita calcinada e do fonolito, granulados com dois materiais orgânicos, sobre o crescimento do milho em vasos, em duas classes de solos, em ambiente controlado. Foi avaliado 8 fontes de potássio (K) (Fonolito; Fonolito + esterco de galinha; Fonolito + esterco de curral; Glauconita calcinada; Glauconita calcinada + esterco de galinha; Glauconita calcinada + esterco de curral; Controle (sem K); Controle (K - KCl) e dois solos distintos em relação à textura. O experimento foi conduzido por um período de 38 dias. Foram realizadas as análises de altura de plantas, diâmetro do colmo, massa seca de parte aérea, número de folhas, teores foliares de N, P, K, e índice SPAD. A fonte fonolito + esterco de galinha equipara-se ao $\mathrm{KCl}$ na altura de plantas, diâmetro do colmo e massa seca de parte aérea avaliados no solo arenoso. No solo argiloso, as duas rochas quando associadas aos resíduos orgânicos, proporcionam efeito similar ao $\mathrm{KCl}$ para a massa seca de parte aérea. O uso das rochas granuladas, glauconita na forma calcinada e do fonolito, puras, sem mistura com resíduos orgânicos, não foram eficientes para disponibilizar o $\mathrm{K}$ para as plantas de milho.
\end{abstract}

Termos para indexação: Zea mays; fonolito; glauconita calcinada.

\section{INTRODUCTION}

Potassium is the most commonly applied crop nutrient in the Brazilian agriculture, mostly applied as potassium chloride $(\mathrm{KCl})$. In 2018 , the use of potassium oxide $\left(\mathrm{K}_{2} \mathrm{O}\right)$ reached nearly 5.8 million tons in the country (ANDA, 2018).

Brazil is the largest importer of $\mathrm{K}$ fertilizers in the world, since, on average, only $5 \%$ of all $\mathrm{K}$ consumed in the Brazilian agriculture is produced in the country (Nascimento; Loureiro, 2004; Oliveira, 2016).
One possibility for countries with low availability of soluble $\mathrm{K}$ sources is to encourage research on the development of new fertilizer technologies, including alternative sources.

Adding sources of rock minerals to the soil might be a strategic option for Brazil, given the country's growing agricultural challenge. Although it may seem like a novelty, the benefits of adding sources of rock minerals such as liming and phosphate to the soil are not new (Meert et al., 2009). Nevertheless, for nutrients demanded in larger 
quantities by crops, such as $\mathrm{K}$, there are still restrictions on the use of these materials due to the low solubility of the rocks. In this case, one option is the input of external energy in the production of fertilizers obtained from these rocks, or its association with an organic matrix that promotes greater agronomic efficiency of these products. For example, Tavares et al. (2018) showed that the use of phonolite associated with organic compost was efficient to increase the content of $\mathrm{K}$ in dry mass of Brachiaria grass and soil.

There are challenges related to the use of rocks as fertilizers, such as providing nutrients in the correct amounts and at the right time for each crop (Harley; Gilkes, 2000). Studies showed that most Brazilian rocks, such as glauconite, present low capacity, or are even not able, to supply K to plants (Santos et al., 2016; Silva et al., 2012), especially in rocks with potential K sources, consisting of silicate minerals, potassium feldspars, micas, vermiculites and smectites (Curi; Kämpf; Marques, 2005).

Nevertheless, there have been processes aiming to optimize the efficiency of the use of rocks with potential K sources. For example, grinding, which increases the contact surface of the minerals with the soil, chemical changes such as mineral acidification, and also thermal processes such as calcination with and without the addition of limestone that alters the crystalline structure of minerals, as well as weathering itself, can improve the solubility and the nutrient release capacity of the sources (Santos et al., 2015; Straaten, 2006).

The process of calcination (Martins et al., 20015) and acidification (Santos et al., 2016) of glauconite was efficient to increase K solubility when extracted in water and citric acid. The effect of these processes also enabled the increase of $\mathrm{K}$ availability for Mombasa grass and maize when compared with the use of fresh rock (Santos et al., 2016). Moreover, the calcination process was also efficient to increase the release efficiency of $\mathrm{K}$ in glauconite in ornamental plants (Boldrin et al., 2019) and in millets (Duarte et al., 2015).

Given the limitations of solubility and the agronomic efficiency, some rocks or minerals that have high $\mathrm{K}$ contents may be alternative sources for the production of $\mathrm{K}$ salts or for application in soils as slow solubilizing potassium fertilizers (Nascimento; LapidoLoureiro, 2009). Their efficiency depends on the initial $\mathrm{K}$ concentrations in the rock and the treatment to which the rock was submitted.
Therefore, this study aimed to evaluate the agronomic viability of using calcined glauconite and phonolite blended and granulated with two organic manures on maize growth in two soils of contrasting textures.

\section{MATERIAL AND METHODS}

The experiment was carried out under greenhouse conditions using maize as an indicator species. Granulated fertilizers were produced using two rocks and two organic wastes. The experiment was conducted in two soils of contrasting textures: a sandy soil and a clayey soil.

The experiment followed a randomized complete design in a $8 \times 2$ factorial scheme, which consisted of eight sources of $\mathrm{K}$ : phonolite; phonolite + poultry manure; phonolite + cattle manure; calcined glauconite; calcined glauconite + poultry manure; calcined glauconite + cattle manure; negative control (no K); and positive control $(\mathrm{K}-\mathrm{KCl})$, and two soils of contrasting textures regarding their clay content (clayey soil: $500 \mathrm{~g} \mathrm{~kg}^{-1}$ clay and sandy soil: $130 \mathrm{~g} \mathrm{~kg}^{-1}$ clay). All K fertilizers were applied as a granulated form (granules size between 2 and $4 \mathrm{~mm}$ ).

Liming was performed based on the initial chemical analysis of the soil (Table 1) to raise the base saturation to $60 \%$, with subsequent incubation for $30 \mathrm{~d}$. The treatments were applied individually in each pot, and a dose of $150 \mathrm{mg}$ $\mathrm{dm}^{-3} \mathrm{~K}$ was used based on the total $\mathrm{K}_{2} \mathrm{O}$ content of the sources.

The $\mathrm{K}$ dose was determined by previous studies of growth response curves for maize as a function of increasing $\mathrm{K}$ doses, which indicated that $150 \mathrm{mg} \mathrm{dm}^{-3}$ of $\mathrm{K}$ corresponds to a dose responsive to both soils. The amount applied from each source was calculated based on the $\mathrm{K}$ contents extracted from hydrofluoric acid present in the fertilizers produced (Table 2). Thus, $2170.77 \mathrm{mg} \mathrm{dm}^{-3}$ calcinated glauconite, $2890.17 \mathrm{mg} \mathrm{dm}^{-3}$ of phonolite, $2707.58 \mathrm{mg} \mathrm{dm}^{-3}$ calcinated glauconite + chicken manure, $2205.88 \mathrm{mg} \mathrm{dm}^{-3}$ phonolite + chicken manure, $2640.85 \mathrm{mg} \mathrm{dm}^{-3}$ calcined glauconite + cattle manure, $2772.64 \mathrm{mg} \mathrm{dm}^{-3}$ phonolite + cattle manure and $301.33 \mathrm{mg} \mathrm{dm}^{-3} \mathrm{KCl}$ were applied.

For the production of the granulated fertilizers, rocks combined with two organic matrices (cattle manure and chicken manure) were used. The proportion of powder rock mixture with the organic waste was $50 \%$ (weight basis) for each additive. The blending was ground and sieved to pass a $0.25-\mathrm{mm}$ sieve ( $60 \mathrm{mesh}$ ) for standardization and homogenization. 
Table 1: Attributes of the soils used in the study prior to the experiment.

\begin{tabular}{ccccccccccccc}
\hline Soil & $\left.\mathrm{pH} \mathrm{CaCl}_{2}\right)$ & $\mathrm{P}$ & $\mathrm{S}$ & $\mathrm{K}$ & $\mathrm{Ca}$ & $\mathrm{Mg}$ & $\begin{array}{c}\mathrm{Al} \\
\mathrm{H}+\mathrm{Al}\end{array}$ & $\begin{array}{c}\mathrm{O} . \mathrm{M} \\
\text { Sand }\end{array}$ & $\begin{array}{c}\text { Silt } \\
\text { Clay }\end{array}$ \\
\hline Sandy & 4.1 & 1.3 & 4.1 & 31.2 & 0.83 & 0.48 & 0.53 & 4.00 & 29.3 & 83 & 4 & 13 \\
Clayey & 4.0 & 0.3 & 3.6 & 42.9 & 0.57 & 0.34 & 0.75 & 3.75 & 32.6 & 42 & 8 & 50 \\
\hline
\end{tabular}

$\mathrm{P}$ and $\mathrm{K}$ in Mehlich-1; O.M: organic matter determination by colorimetric method; $\mathrm{Ca}$ and $\mathrm{Mg}$ in $\mathrm{KCl} ; \mathrm{S}-\mathrm{SO}_{4}{ }_{4}^{2:} \mathrm{S}$ in the form of sulphates, extracted by calcium phosphate and determined by colorimetry; $\mathrm{Al}^{3+}$ : Exchangeable aluminum, extracted by $1 \mathrm{~mol}$ $\mathrm{L}^{-1}$ potassium chloride solution; $\mathrm{H}+\mathrm{Al}$ : total soil acidity, determined in SMP buffer solution at $\mathrm{pH}$ 7,5.

Table 2: Chemical characterization of the produced fertilizers.

\begin{tabular}{cccccc}
\hline Materials & $\mathrm{P}_{2} \mathrm{O}_{5}$ & $\mathrm{~K}_{2} \mathrm{O}_{\text {Sol }}$ & $\mathrm{K}_{2} \mathrm{O}_{\text {Total }}$ & $\mathrm{K}_{2} \mathrm{O}_{\text {Aqua regia }}$ & $\mathrm{K}_{2} \mathrm{O}_{\mathrm{HF}}$ \\
& $\%$ & $\%$ & $\%$ & $\%$ & $\%$ \\
\hline Calcined Glauconite & 0.06 & $<1$ & 1.26 & 1.69 & 6.91 \\
Phonolite & $<0.05$ & $<1$ & 0.9 & 1.14 & 5.19 \\
Calcined Glauconite + chicken manure & 2.79 & 1.82 & 2.71 & 2.95 & 5.54 \\
Phonolite + chicken manure & 2.66 & 1.670 & 2.53 & 2.65 & 6.80 \\
Calcined Glauconite + cattle manure & 0.53 & $<1$ & 1.38 & 1.56 & 5.68 \\
Phonolite + cattle manure & 0.4 & $<1$ & 0.96 & 1.17 & 5.41 \\
\hline
\end{tabular}

$\mathrm{K}_{2} \mathrm{O}_{\text {sol }}: \mathrm{H}_{2} \mathrm{O}$ soluble $\mathrm{K}_{2} \mathrm{O} ; \mathrm{K}_{2} \mathrm{O}_{\mathrm{HF}}: \mathrm{K}_{2} \mathrm{O}$ extracted by hydrofluoric acid; $\mathrm{K}_{2} \mathrm{O}_{\text {Aqua regia }}: \mathrm{K}_{2} \mathrm{O}$ extracted by aqua regia (concentrated nitric and hydrochloric acids).

The production of the granulated fertilizers was carried out in a 12-L bench top granulator (MAP type MLH12U1VA20g - Mixing Technology - WAMGROUP), in which 3\% RD 545 additive (binder agent - Ingredion Brasil SA) was mixed to the solids, followed by gradual addition of water. Subsequently, the pellets were dried at $60{ }^{\circ} \mathrm{C}$ in a forced-circulation oven until constant weight.

On the same day of the treatment applications, eight maize seeds were sown per pot containing $5 \mathrm{dm}^{3}$ soil. After germination, the seedlings were thinned leaving only two plants per pot.

The pots were fertilized according to Malavolta, Vitti and Oliveira (1997): $300 \mathrm{mg} \mathrm{dm}^{-3} \mathrm{~N}$, split as 162.6 $\mathrm{mg} \mathrm{dm}^{-3}$ at planting and the rest after cultivation, $250 \mathrm{mg}$ $\mathrm{dm}^{-3} \mathrm{P}, 60 \mathrm{mg} \mathrm{dm}^{-3} \mathrm{~S}, 1.5 \mathrm{mg} \mathrm{dm}^{-3} \mathrm{Cu}, 0.5 \mathrm{mg} \mathrm{dm}^{-3} \mathrm{~B}$, $0.15 \mathrm{mg} \mathrm{dm}^{-3} \mathrm{Mo}, 5 \mathrm{mg} \mathrm{dm}^{-3} \mathrm{Zn}$ and $3.6 \mathrm{mg} \mathrm{dm}^{-3} \mathrm{Mn}$, using $\mathrm{NH}_{4} \mathrm{H}_{2} \mathrm{PO}_{4},\left(\mathrm{NH}_{4}\right)_{2} \mathrm{SO}_{4}, \mathrm{NH}_{4} \mathrm{NO}_{3}, \mathrm{CuSO}_{4} .5 \mathrm{H}_{2} \mathrm{O}$, $\mathrm{H}_{3} \mathrm{BO}_{3},\left(\mathrm{NH}_{4}\right)_{6} \mathrm{Mo}_{7} \mathrm{O}_{24} \cdot 4 \mathrm{H}_{2} \mathrm{O}, \mathrm{ZnSO}_{4} \cdot 7 \mathrm{H}_{2} \mathrm{O}, \mathrm{MnCl}_{2} \cdot 4 \mathrm{H}_{2} \mathrm{O}$, as sources, respectively.

During the experiment, the pots were irrigated with deionized water by daily controlling the weight of the pot+soil+plants, replacing the water lost by evapotranspiration in order to maintain $60 \%$ of the total pore volume.
The plants were cultivated for $38 \mathrm{~d}$. After this period, the following parameters were evaluated: plant height, stem diameter, leaf number and SPAD chlorophyll meter (SPAD-502, Minolta Camera Co. Ltd., Japan). After harvesting, the plants were separated into shoots and roots. The shoot was dried in a forced circulation oven at $65^{\circ} \mathrm{C}$ and the shoot dry mass was determined. Then, the material was ground in a Willey mill to evaluate the contents of N, P, K, Mg, Ca and Mn (Malavolta; Vitti; Oliveira, 1997). The nutrient accumulation in the shoot was calculated by multiplying the content of each nutrient by the dry weight of shoot for each treatment.

For the two soils of contrasting textures, were estimated the potassium recovery rate (KRR) and the relative agronomic efficiency (RAE), as follow:

At the end of the experiment, a composite sample was collected from the soil to quantify the content of $\mathrm{K}$ in each treatment, with extraction by the Mehlich-1 method and subsequent determination by the direct flame photometer method (Teixeira et al., 2017).

The obtained data were submitted to analysis of variance and, when significant, by the $F$ test $(p<0.05)$. The averages were compared by the Scott-Knott test ( $\mathrm{p}$ $<0.05$ ), using SISVAR statistical software (Ferreira, 2011). 


$$
\begin{aligned}
& K R R=\frac{(\mathrm{K} \text { accumulated in the tested treatment }-\mathrm{K} \text { accumulated in the control treatment })}{\text { Total } \mathrm{K} \text { applied }} \times 100 \\
& R A E=\frac{(\mathrm{K} \text { accumulated in the tested treatment }-\mathrm{K} \text { accumulated in the control treatment })}{\text { (K accumulated in the } \mathrm{KCl} \text { treatment }-\mathrm{K} \text { accumulated in the control treatment) }} \times 100
\end{aligned}
$$

\section{RESULTS AND DISCUSSION}

The analyzed data presented a significant effect of interaction between $\mathrm{K}$ sources and soils for plant height (Figure 1A), shoot dry mass (Figure 1B) and stem diameter (Figure 1C). In the sandy soil, plant height and stem diameter of maize plants submitted to the $\mathrm{K}-\mathrm{KCl}$ and phonolite + chicken manure treatments did not differ from each other and were higher than the other sources. On the other hand, the lowest means of these variables were observed in the plants that received phonolite and the negative control treatment. In the clayey soil, there were no significant differences between the sources for these variables. In the $\mathrm{K}-\mathrm{KCl}$ treatment, plant height was higher in the sandy soil when compared with the clayey soil. Nevertheless, an opposite behavior was observed for the treatment using phonolite (Figure 1A).

Maize plants presented larger stem diameter in the clayey soil when the following sources were applied: calcined glauconite, phonolite and no K (negative control). As for the sandy soil, this variable presented higher values for the source phonolite + chicken manure (Figure 1C).

There was also a significant effect of interaction between $\mathrm{K}$ sources and soils for shoot dry mass (Figure 1B). In the sandy soil, the plants of the phonolite + chicken manure and $\mathrm{K}-\mathrm{KCl}$ treatments presented higher shoot dry mass in relation to the other treatments. The treatment without $\mathrm{K}$ application and fertilizers containing pure rocks promoted lower dry mass values of maize plants in both soils. Higher shoot dry mass was observed in maize plants grown in the sandy soil that received phonolite + chicken manure and $\mathrm{K}-\mathrm{KCl}$ as sources. Regarding the phonolite treatment, the plants presented higher shoot dry mass when cultivated in the clayey soil.

There was a significant effect only on the number of leaves of maize plants. The plants presented higher leaf number in the clayey soil, regardless of the $\mathrm{K}$ source (Figure 1D).

For the contents of $\mathrm{N}$ in the shoot, the there was only an effect for the K sources. The content of leaf $\mathrm{N}$ was higher in plants that received the application of calcined glauconite, phonolite, calcined glauconite + chicken manure, calcined glauconite + cattle manure and no $\mathrm{K}$ application, regardless of the evaluated soil (Table 3).

For the contents of $\mathrm{P}$ and $\mathrm{K}$ in the shoot, there was an effect of the interaction between the sources of $\mathrm{K}$ and the soils. For the sandy soil, the plants presented higher levels of $\mathrm{P}$ when not fertilized with $\mathrm{K}$ and the lowest levels were found with the application of phonolite + chicken manure and $\mathrm{K}$ in the form of $\mathrm{KCl}$. There were no differences between means for $\mathrm{P}$ sources when plants were cultivated in the clayey soil (Table 3 ). Regarding the contents of $\mathrm{K}$ in the shoot, for both soils, the highest values were found when the plants received fertilization of $\mathrm{K}$ in the form of $\mathrm{KCl}$ (Table 3).

There was a significant effect of the interaction of the $\mathrm{K}$ sources and soils for the accumulations of $\mathrm{N}, \mathrm{P}$ and $\mathrm{K}$. In the clayey soil, $\mathrm{N}$ and $\mathrm{P}$ accumulations in the shoot were not influenced by the K sources (Table 3 ).

In the sandy soil, the plants that received the application of calcined glauconite + chicken manure, phonolite + chicken manure and $\mathrm{KCl}$ presented the highest $\mathrm{N}$ accumulation in the shoots. The control treatments, pure $\mathrm{KCl}$ and no $\mathrm{K}$ application, presented the lowest accumulations for the nutrient (Table 3). Probably the observed $\mathrm{N}$ accumulation for the calcined glauconite + chicken manure source was due to a nutrient concentration effect due to the lower shoot dry mass when compared with $\mathrm{KCl}$ and phonolite + chicken manure.

In the sandy soil, the plants presented the highest accumulation of $\mathrm{P}$ in the shoot when the phonolite + chicken manure, calcined glauconite + cattle manure, phonolite + cattle manure and $\mathrm{KCl}$ sources were applied (Table 3). The accumulation of $\mathrm{P}$ for calcined glauconite + cattle manure, phonolite + cattle manure is associated with the effect of nutrient concentration.

The highest $\mathrm{K}$ accumulations in shoots for both soils were observed when plants received $\mathrm{KCl}$ application. On the other hand, the smallest $\mathrm{K}$ accumulations in the shoots for the sandy soil were observed when $\mathrm{K}$ was not applied, as well as pure rocks and glauconite associated with both organic sources. In the clayey soil, the smallest accumulations for the nutrient in the shoots were observed when $\mathrm{K}$ was not applied, as well as the pure rocks and the phonolite + cattle manure source (Table 3 ). 

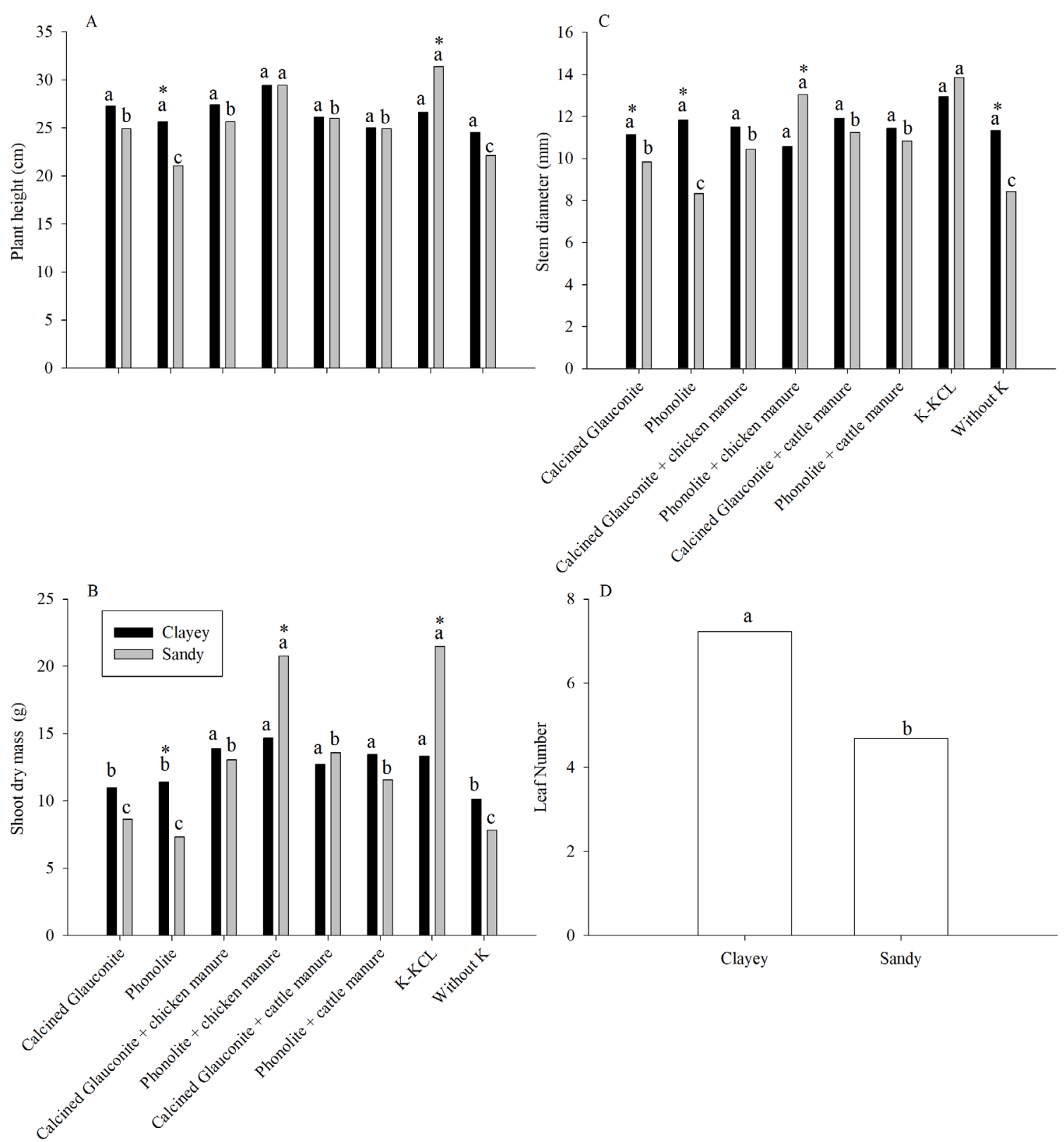

Figure 1: Plant height $(A)$, shoot dry mass $(B)$ and stem diameter $(C)$ as a function of the application of the different fertilizers; and leaf number (D) as a function of soil textural classes. Means followed by the same letter - for graphs A, B and C comparing different sources of potassium for each soil and for graph D comparing soils do not differ from each other. Asterisk $(*)$ compares the soils within each nutrient source. Scott-Knott $(p<0.05)$.

Santos et al. (2016), when comparing application efficiency of in natura glauconite, acidified glauconite (industrial acid metallurgical effluent - mixture of $\mathrm{H}_{2} \mathrm{SO}_{4}$, $\mathrm{HF}$ and $\mathrm{HCl}$ ), calcined glauconite and $\mathrm{KCl}$, verified the low efficiency of $\mathrm{K}$ utilization by maize and eucalyptus. In Mombasa grass, in natura glauconite was able to increase the $\mathrm{K}$ content in the plant. The authors verified that both acidification and calcination provided $\mathrm{K}$ and allowed the increase of leaf content in maize and eucalyptus. This behavior corroborates the potential of external energy input to increase the efficiency of nutrient sources produced from low solubility rocks. 
Table 3: Contents of N, P and $\mathrm{K}$ and their accumulations in shoots and shoot dry mass.

\begin{tabular}{|c|c|c|c|c|c|c|c|c|}
\hline \multirow{2}{*}{ Soil } & \multirow{2}{*}{ Potassium source } & \multirow{2}{*}{$\begin{array}{c}\text { shoot dry } \\
\left.\text { mass (g pot }{ }^{-1}\right)\end{array}$} & \multicolumn{3}{|c|}{ Content $\left(\mathrm{g} \mathrm{kg}^{-1}\right)$} & \multicolumn{3}{|c|}{ Accumulation (mg pot $\left.{ }^{-1}\right)$} \\
\hline & & & $\mathrm{N}$ & $P$ & $\mathrm{~K}$ & $\mathrm{~N}$ & $P$ & $\mathrm{~K}$ \\
\hline \multirow{8}{*}{-} & Calcined glauconite & 10.21 & $46.09 a$ & 5.18 & 7.63 & 467.56 & 48.73 & 74.20 \\
\hline & Phonolite & 9.37 & $50.53 a$ & 5.78 & 7.51 & 466.54 & 48.89 & 68.02 \\
\hline & $\begin{array}{l}\text { Calcined glauconite + } \\
\text { chicken manure }\end{array}$ & 13.46 & $49.11 a$ & 4.83 & 8.29 & 657.37 & 64.08 & 111.78 \\
\hline & $\begin{array}{l}\text { Phonolite }+ \text { chicken } \\
\text { manure }\end{array}$ & 17.17 & $40.29 b$ & 4.67 & 10.29 & 699.65 & 86.58 & 167.88 \\
\hline & $\begin{array}{l}\text { Calcined glauconite }+ \text { cattle } \\
\text { manure }\end{array}$ & 12.54 & $44.56 a$ & 5.75 & 8.73 & 558.39 & 77.18 & 112.07 \\
\hline & Phonolite + cattle manure & 12,75 & $40.69 b$ & 6.79 & 13.13 & 508.62 & 80.46 & 162.71 \\
\hline & $\mathrm{K}-\mathrm{KCl}$ & 18.33 & $37.52 b$ & 3.93 & 25.32 & 693.28 & 73.28 & 474.07 \\
\hline & No K & 8.99 & $43.86 a$ & 7.78 & 8.76 & 391.52 & 64.30 & 76.82 \\
\hline \multirow{8}{*}{ Sandy } & Calcined glauconite & 8.63 & 44.63 & $7.13 d$ & $7.97 c$ & $385.70 c$ & $61.67 c$ & $68.59 d$ \\
\hline & Phonolite & 731 & 53.59 & $8.17 c$ & $8.59 c$ & $390.55 c$ & $59.57 c$ & $62.91 d$ \\
\hline & $\begin{array}{l}\text { Calcined glauconite + } \\
\text { chicken manure }\end{array}$ & 13.04 & 59.28 & $6.86 d$ & $8.28 c$ & 773.96a & $89.21 b$ & $107.96 d$ \\
\hline & $\begin{array}{l}\text { Phonolite + chicken } \\
\text { manure }\end{array}$ & 20.78 & 42.66 & $6.03 e$ & $8.28 c$ & $884.75 a$ & $124.68 a$ & $171.27 c$ \\
\hline & $\begin{array}{l}\text { Calcined glauconite }+ \text { cattle } \\
\text { manure }\end{array}$ & 12.35 & 50.17 & $8.45 c$ & $7.92 \mathrm{c}$ & $620.66 b$ & $115.72 a$ & $103.12 d$ \\
\hline & Phonolite + cattle manure & 10.96 & 46.67 & $9.73 b$ & $19.17 b$ & $511.88 b$ & $110.05 a$ & $224.09 b$ \\
\hline & $\mathrm{K}-\mathrm{KCl}$ & 21.47 & 40.03 & $5.23 \mathrm{e}$ & $30.63 a$ & $856.19 a$ & $111.17 a$ & $655.94 a$ \\
\hline & Without K & 7.83 & 47.03 & $12.02 \mathrm{a}$ & $9.84 \mathrm{c}$ & $370.33 c$ & $93.11 b$ & $76.64 d$ \\
\hline \multirow{8}{*}{ Clayey } & Calcined glauconite & 11.79 & 47.54 & $3.23 a$ & $7.29 c$ & $549.40 a$ & $35.78 a$ & $79.80 d$ \\
\hline & Phonolite & 11.42 & 47.47 & $3.38 a$ & $6.41 \mathrm{c}$ & $542.53 a$ & $38.20 a$ & $73.12 d$ \\
\hline & $\begin{array}{l}\text { Calcined glauconite + } \\
\text { chicken manure }\end{array}$ & 13.88 & 38.94 & $2.79 a$ & $8.28 c$ & $540.77 a$ & $38.94 a$ & $115.60 c$ \\
\hline & $\begin{array}{l}\text { Phonolite }+ \text { chicken } \\
\text { manure }\end{array}$ & 13.56 & 37.92 & $3.31 a$ & $12.29 b$ & $514.54 a$ & $48.47 a$ & $164.49 b$ \\
\hline & $\begin{array}{l}\text { Calcined glauconite }+ \text { cattle } \\
\text { manure }\end{array}$ & 12.73 & 38.94 & $3.04 a$ & $9.53 b$ & $496.12 a$ & $38.64 a$ & $121.02 c$ \\
\hline & Phonolite + cattle manure & 14.54 & 34.71 & $3.84 a$ & $7.08 \mathrm{c}$ & $505.36 a$ & $50.86 a$ & $101.33 d$ \\
\hline & $\mathrm{K}-\mathrm{KCl}$ & 15.20 & 35.00 & $2.64 a$ & $20.00 a$ & $530.36 a$ & $35.38 a$ & $292.19 a$ \\
\hline & Withou K & 10.14 & 40.69 & $3.53 a$ & $7.66 c$ & $412.68 a$ & $35.49 a$ & $76.99 d$ \\
\hline
\end{tabular}

Means followed by the same letter in the column do not differ from each other by the Scott-Knott test $(p<0.05)$.

Only the effect of the K sources was observed regardless of soil type for the SPAD index (Figure 2). The plants fertilized with phonolite + chicken manure and $\mathrm{KCl}$ presented higher SPAD index values when compared with those receiving the other $\mathrm{K}$ sources. The SPAD index is related to chlorophyll content in the plant or leaf green intensity, thus expressing nitrogen nutritional status at a specific stage of the crop cycle (Silva et al., 2011). When comparing SPAD meters results with $\mathrm{N}$ content and accumulation in the sandy soil (Table 3 ), it can be observed that the sources phonolite + chicken manure and $\mathrm{KCl}$ also presented higher nutrient accumulation. 


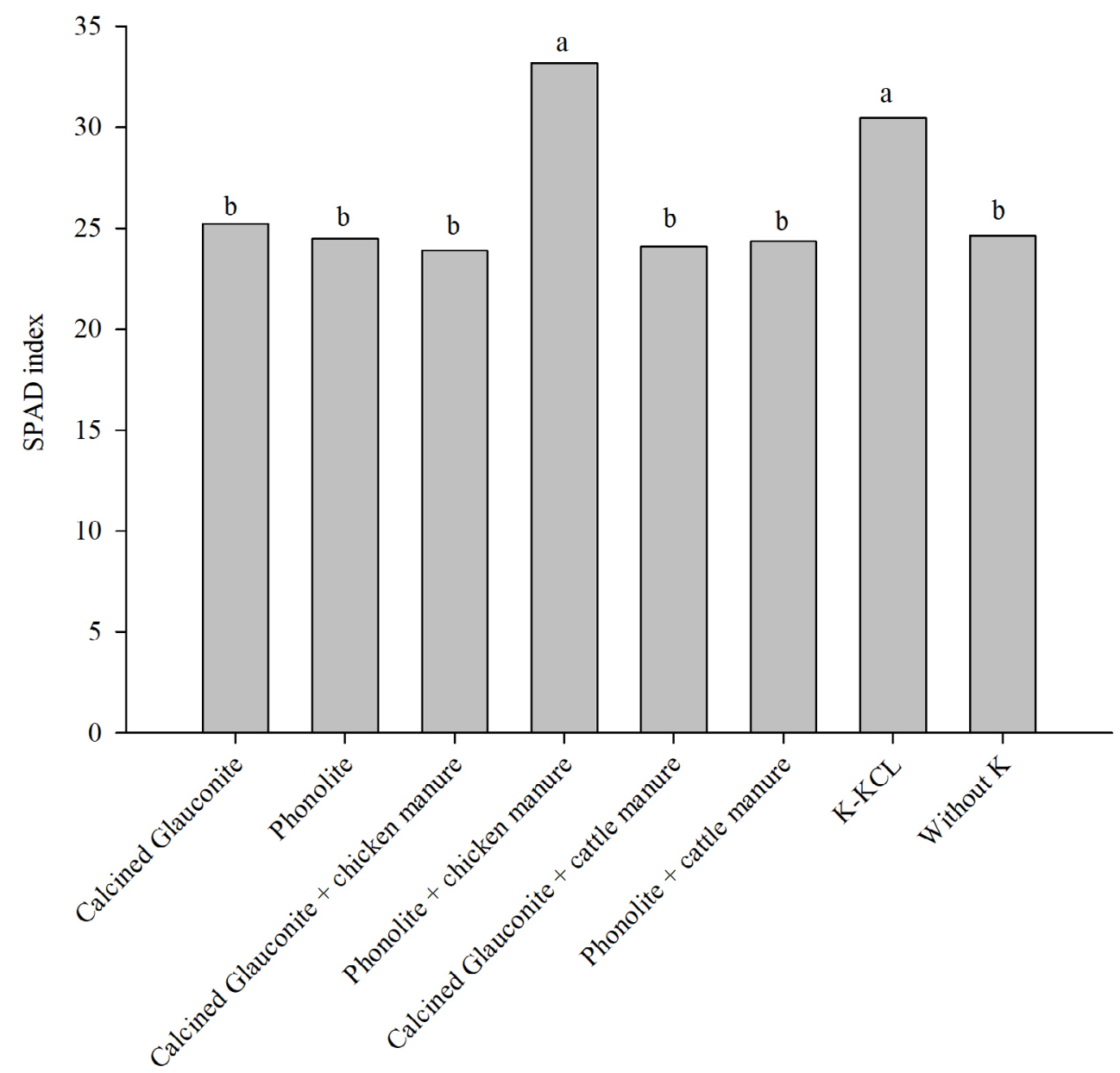

Figure 2: SPAD index as a function of the fertilizer sources. Means followed by the same letter do not differ from each other. Scott-Knott $(p<0.05)$.

After the plants were harvested, the soil contents of $\mathrm{K}$ in each pot were analyzed. There was an effect of the interaction between the $\mathrm{K}$ sources and soils on soil $\mathrm{K}$ content after maize cultivation (Figure 3). Regardless of the source, the content of soil $\mathrm{K}$ was higher in the clayey soil when compared with the sandy soil, following the results of the initial soil analysis (Table 1). For the sandy soil, there was no significant difference between the sources for soil K contents. On the other hand, in the clayey soil, the highest soil $\mathrm{K}$ contents were found in the pots fertilized with $\mathrm{KCl}$, followed by those fertilized with phonolite + chicken manure. The other treatments were lower than $\mathrm{KCl}$ and phonolite + chicken manure, showing no difference between them.

The results of the contents of soil $\mathrm{K}$ reflect the nutrient accumulation in shoots in plants grown in clayey soils (Table 3), since the highest $\mathrm{K}$ accumulations were for the source $\mathrm{KCl}$ and phonolite + chicken manure.
In the sandy soil, plants treated with the phonolite + chicken manure source present similar results when compared with the plants treated with $\mathrm{KCl}$ regarding plant height, stem diameter and shoot dry mass. For the clayey soil, both fertilizers produced from the association of the rocks with the organic matrices provided similar effect to $\mathrm{KCl}$ in the shoot dry mass values of the maize plants (Figure 1).

The KRR data showed that, for the sandy soil, 77.24 $\% \mathrm{~K}$ applied with $\mathrm{KCl}$ was uptaken by the corn plants while the application of the pure rock did not supply $\mathrm{K}$ to the plants. When the rocks were combined with both manures the phonolite uptake more $\mathrm{K}$ comparing to calcinated glauconite (Table 4). For the clayey soil the KRR was also higher for the $\mathrm{KCl}$ than the other $\mathrm{K}$ sources, but in comparison to the sandy soil was 2.7 times smaller, that difference can be attributed to the higher buffering power of clayey soil due to the higher percentage of clay and organic matter. 


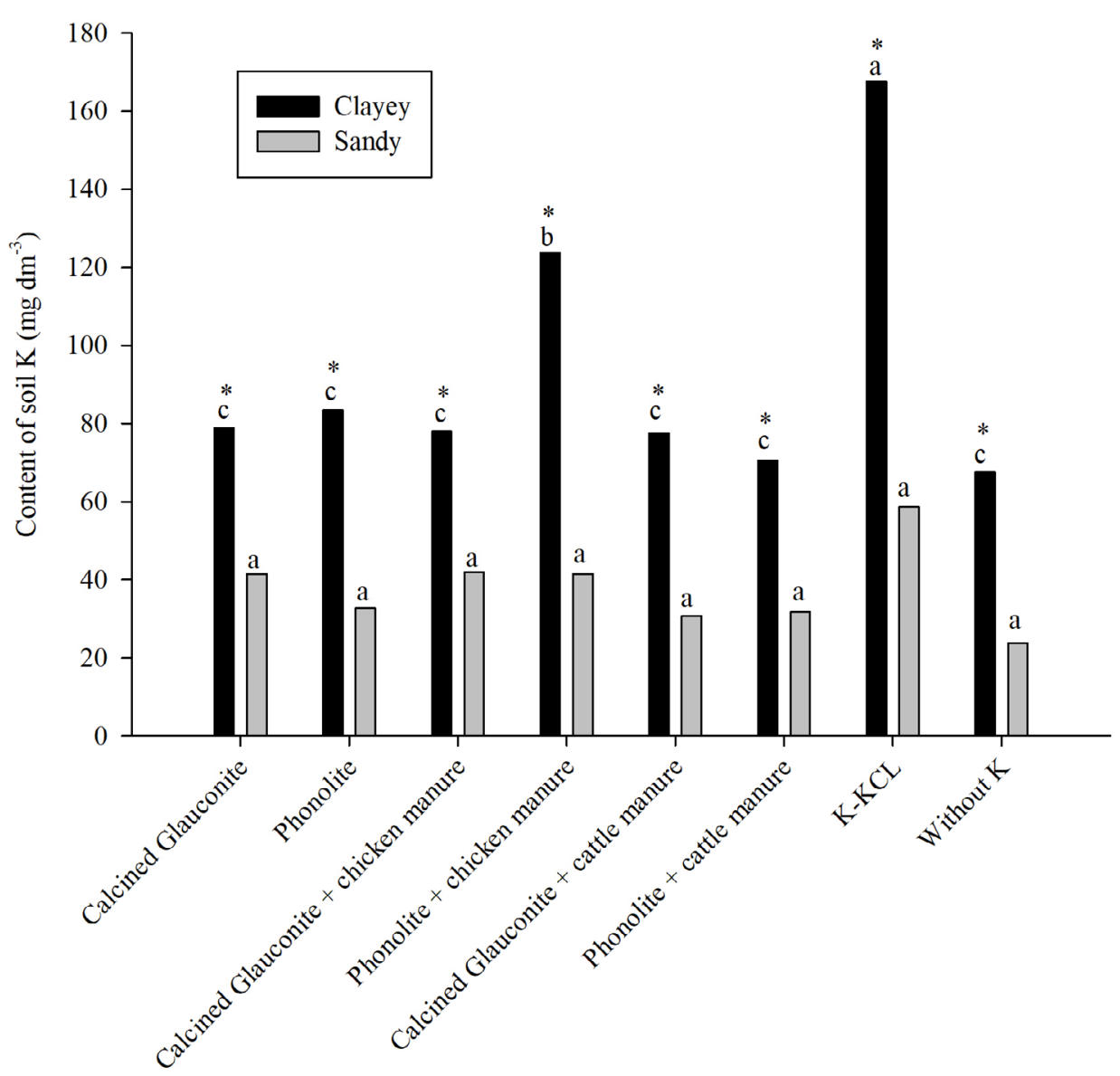

Figure 3: Contents of soil $\mathrm{K}$ as a function of the different fertilizers after the experiment (residual). Means followed by the same letter comparing sources of fertilization for each soil do not differ from each other. Asterisk $\left.{ }^{*}\right)$ compares the soil types within each fertilizer source. Scott-Knott $(p<0.05)$.

Comparing the efficiency of the $\mathrm{K}$ sources with the $\mathrm{KCl}$ according to the plant growth, for the sandy soil, the RAE for the phonolite + chicken manure was similar to the $\mathrm{KCl}$ in terms of the shoot dry mass, even though this source had presented a low KRR, possibly the reasons that allowed the plant growth to this treatment were other than only the availability of $\mathrm{K}$. On the other hand, the pure rocks presented 5.87 and $0 \%$ of RAE for calcinated glauconite and phonolite, respectively (Table 4). In general, the RAE for the clayey soil was higher than the sandy soil, the addition of the manures to the both rocks assured an increase of RAE comparing to the pure rocks. The upper RAE for the clayey soil can be attributed to the amount of clay and organic matter that triggers important differences between the soils, such as buffering power that affect the availability of all the nutrients in the soil solution, for example.
In general, the comparison of the effect between $\mathrm{K}$ fertilizers and $\mathrm{KCl}$ in the analyzed variables during the evaluated period suggests that the ability to supply $\mathrm{K}$ to maize plants was always associated with the blending with the organic sources, since the use of pure rocks was not efficient in nutrient availability. It can be inferred that the short conduction period of the experiment might not have been sufficient to provide the nutrient from fertilizers produced from rocks, and that there might have been an effect of K mineralization from the organic sources (Silva, 2008). The application of fertilizers in the granulated form associated with the cultivation of plants for only $38 \mathrm{~d}$ might have been the cause of the low efficiency of $\mathrm{K}$ release in the use of calcined glauconite, due to the smaller contact surface of the fertilizer with the soil. These results differ from those shown by Boldrin et al. (2019); Duarte et al. (2015) and Santos et al. (2016), who showed that the use 
Table 4: Potassium recovery rate (KRR) and relative agronomic efficiency (RAE) of potassium sources in two soils of contrasting textures.

\begin{tabular}{cccc}
\hline Soil & Potassium source & KRR (\%) & RAE (\%) \\
\hline Calcined glauconite & 0 & 5.87 \\
Sandy & Phonolite & 0 & 0 \\
& Calcined glauconite + chicken manure & 4.18 & 38.19 \\
& Phonolite + chicken manure & 12.62 & 94.96 \\
& Calcined glauconite + cattle manure & 3.53 & 33.16 \\
& Phonolite + cattle manure & 19.66 & 22.91 \\
K-KCl & 77.24 & 100.00 \\
\hline Clayey & Calcined glauconite & 0.37 & 32.67 \\
& Phonolite & 0 & 25.30 \\
& Calcined glauconite + chicken manure & 5.15 & 73.86 \\
& Phonolite + chicken manure & 11.67 & 67.59 \\
& Calcined glauconite + cattle manure & 5.87 & 51.09 \\
& Phonolite + cattle manure & 3.24 & 87.02 \\
& K-KCl & 28.69 & 100.00 \\
\hline
\end{tabular}

of calcined glauconite allowed the release of $\mathrm{K}$ and its utilization by plants.

Similarly to the results of leaf K content (Table 3 ) and available soil content after the experiment (Figure 3), the application of fresh glauconite in the soil showed low efficiency in providing $\mathrm{K}$ for grasses, which was as also reported by other authors (Duarte et al., 2015; Martins et al., 2015).

\section{CONCLUSIONS}

The use of calcined glauconite and phonolite without blending with the organic sources is not efficient to make $\mathrm{K}$ available to the plants once there is no have potassium recovery rate for those sources in clayey and sandy soils. The source phonolite + chicken manure is similar to $\mathrm{KCl}$ for the plant growth and proved by the relative agronomic efficiency in the sandy soil. In the clayey and sandy soils, the rocks associated with the organic wastes improve the shoot dry mass production comparing to the pure rocks and present a similar effect to the $\mathrm{KCl}$ source.

\section{ACKNOWLEGMENTS}

This study was carried out with the financial support provided by the University of Rio Verde (UniRV) and the Higher Education Personnel Improvement Coordination - Brazil (CAPES) - funding code 001.

\section{REFERENCES}

ANDA - AGÊNCIA NACIONAL PARA A DIFUSÃO DE ADUBOS. Setor de Fertilizantes - Anuário estatístico 2018. São Paulo, 2018. 265p.

BOLDRIN, K. V. F. et al. Alternative sources of potassium in the growth of calla lily. Scientia Horticulturae, 255:96102, 2019.

CURI, N.; KÄMPF, N.; MARQUES, J. J. Mineralogia e formas de potássio em solos do Brasil. In: YAMADA, T.; ROBERTS, T. L., eds. Potássio na agricultura brasileira. Piracicaba, Associação Brasileira para a Pesquisa da Potassa e do Fosfato, 2005. p.71-92.

DUARTE, I. N. et al. Alternative potash fertilizer source for millet crop. Journal of Plant Nutrition, 38(12):1961-1972, 2015.

FERREIRA, D. F. SISVAR: a computer statistical analysis system. Ciência e Agrotecnologia, 35(6):1039-1042, 2011.

HARLEY, A.; GILKES, R. J. Factors influencing the release of plant nutrient elements from silicate rock powders: A geochemical overview. Nutrient Cycling in Agroecosystems, 56(1):1136, 2000.

MALAVOLTA, E.; VITTI, G. C.; OLIVEIRA, S. A. Avaliação do estado nutricional das plantas: princípios e aplicações. 2.ed. Piracicaba: POTAFOS, 1997. 201p. 
MARTINS, V. et al. Solubilização de potássio em misturas de verdete e calcário tratadas termoquimicamente. Pesquisa Agropecuária Tropical, 45(1):66-72, 2015.

MEERT, L. et al. Produtividade e rentabilidade da soja cultivada com fontes alternativas de nutrientes em Guarapuava, PR. Revista Brasileira de Agroecologia. 4(1):2236-7934, 2009.

NASCIMENTO, M.; LOUREIRO, F. E. L. Fertilizantes e sustentabilidade: o potássio na agricultura brasileira, fontes e rotas alternativas. Rio de Janeiro: CETEM/MCT, (Série Estudos e Documentos, 61), 2004. 66p.

NASCIMENTO, M.; LOUREIRO, F. E. L. Potássio na agricultura brasileira: Fontes e rotas alternativas. In: LOUREIRO, F. E. L.; MELAMED, R. G.; FIGUEIREDO NETO, J. Fertilizantes: agroindústria e sustentabilidade. Rio de Janeiro: CETEM/ MCT, 2009. 645p.

OLIVEIRA, L. A. M. Potássio. In: LIMA T. H.; NEVES, C. A. R. Sumário mineral 2015. Brasília: DNPM; 2016. 135p.

SANTOS, W. O. et al. Thermal and chemical solubilization of verdete for use as potassium fertilizer. International Journal of Mineral Processing, 140(10):72-78, 2015.
SANTOS, W. O. et al. Production and evaluation of potassium fertilizers from silicate rock. Journal of Plant Nutrition and Soil Science, 179(4):547-556, 2016.

SILVA, A. A. S. et al. Verdete from cedro do abaeté as a source of potassium: Characterization, thermal treatment and reaction with CaO. Revista Matéria, 17(3):1062-1074, 2012.

SILVA, C. A. Uso de resíduos orgânicos na agricultura. In: SANTOS, G. A. et al. eds. Fundamentos da matéria orgânica do solo: Ecossistemas tropicais e subtropicais. Porto Alegre: Metrópole, 2008. 636p.

SILVA, M. C. et al. Índice SPAD em função de diferentes horários e posições no folíolo da batata sob fertilização nitrogenada. Revista Ciência Agronômica, 42(4):971-977, 2011.

STRAATEN, P. V. Farming with rocks and minerals: challenges and opportunities. Anais da Academia Brasileira de Ciências, 78(4):731-747, 2006.

TAVARES, L. F. et al. Nutrients release from powder phonolite mediated by bioweathering actions. International Journal of Recycling of Organic Waste in Agriculture, 7(2):89-98, 2018.

TEIXEIRA, P. C. et al. Manual de métodos de análise do solo. 3.ed. Brasília: EMBRAPA, 2017. 573p. 